Western University

Scholarship@Western

Department of Economics Research Reports

Economics Working Papers Archive

1992

\title{
Wage and Price Stickiness in Macroeconomics: An Historical Perspective
}

David Laidler

Follow this and additional works at: https://ir.lib.uwo.ca/economicsresrpt

Part of the Economics Commons

Citation of this paper:

Laidler, David. "Wage and Price Stickiness in Macroeconomics: An Historical Perspective." Department of Economics Research Reports, 9201. London, ON: Department of Economics, University of Western Ontario (1992). 


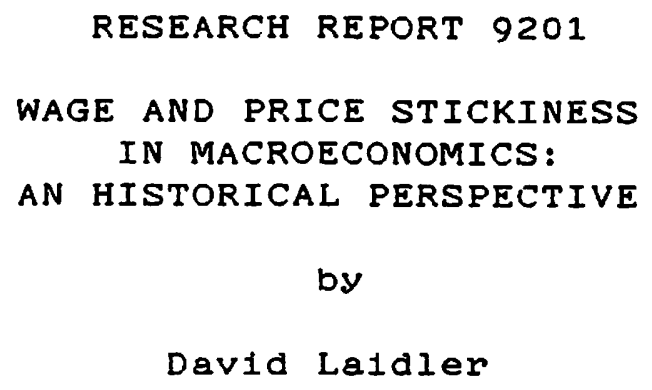

N6A $5 \mathrm{C2}$

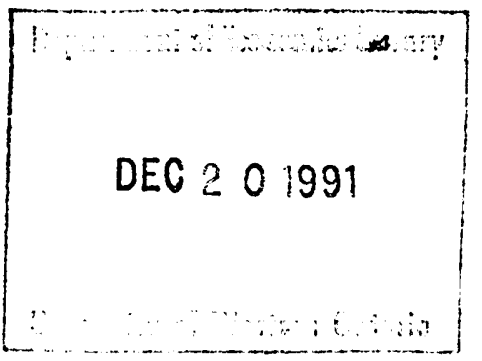




\title{
WAGE AND PRICE STICKINESS IN MACROECONOMICS - AN HISTORICAL PERSPECTIVE*
}

by

\author{
David Laidler
}

The 1991 Henry Thornton Lecture, delivered at the City University, London, England November 20, 1991: This lecture draws upon a broader study of the development of macroeconomics which I am carrying out with the financial aid of the Lynde and Harry Bradley Foundation whose support is gratefully acknowledged. I am indebted to Mr. Toni Gravelle for assistance in the research on which this lecture is based, to Tom Humphrey, John Smithin, Geoffrey Wood and members of the University of Western Ontario, Economic History/History of Economic Thought Workshop, the Economics Department seminar of Kwansei Gakuin University, as well as the York University History of Economic Thought Workshop for many helpful comments. 


\section{INTRODUCTION}

There is more to the history of macroeconomics than a series of bilateral conflicts between competing schools of thought, but such debates have been a significant part of the story. Most recently the competing schools have worn the labels "New-classical" and "NewKeynesian", and the major issue between them has been the role of money wage- and pricestickiness in generating those more or less regular fluctuations in economic activity to which we refer as "the business cycle". For New-classicals, output and employment fluctuations are either responses to shocks to tastes and technology, or to unanticipated shifts in aggregate demand, typically stemming from money supply changes. In either case though, prices give signals to which quantities respond, and variations in real magnitudes take place precisely because prices change. New-Keynesians emphasise demand side shocks, but in their view, quantities vary, not because prices vary, but because they do not.

Now, as I have argued elsewhere (Laidler (1982), Ch.3), the above mentioned characteristic of New-classical economics implies a view of the economy in which Say's Law holds true at each and every moment; and just as surely, in New-Keynesian analysis, that Law -that there cannot exist a state of generalised excess demand or supply for all goods and services (excepting money) -- may be violated for periods of time long enough to matter. Given that "everybody" knows Say's Law to have been the centrepiece of "Classical" economics, and the denial of its universal validity to have been one of the key characteristics of "Keynesian" economics, it would seem at first sight that modern schools of thought have been well named. In this view, the recent renewal of interest in the price stickiness postulate on the part of certain erstwhile exponents of New-classical economics (e.g., Lucas (1989), King (1990)) either signals 
a reaffirmation that Keynesian economics' alleged reliance on wage stickiness did after all represent an important intellectual advance, and that an intriguing attempt to revive older ways of thinking has, in the end failed; or it is a sign that macroeconomists are taking an "easy" option by using a postulate from which it is trivially obvious that fluctuations in real variables can be predicted. In this lecture, I shall argue that either view represents a gross distortion of the historical record.

I shall show: that from the very outset, Classical and Neo-classical economists took money wage, and sometimes price, stickiness for granted, though their relationship to Say's Law, and their potential importance for understanding the cycle, were not recognised until the final quarter of the 19th century; that The General Theory, far from placing additional emphasis on the phenomenon, downgraded its significance, and that Keynes treated money wage stickiness, and therefore price stickiness, as facts of life which had to be taken account of in analyzing the causes and cures of unemployment, while disputing the Neo-classical view that they were, in and of themselves, an important cause of unemployment; that Haberler (1939), Pigou $(1943,1947)$ and Patinkin $(1948,1956)$ extended and clarified certain aspects of Keynes's treatment of the analytic role of wage-price flexibility; that by the time the Phillips Curve came upon the scene, ideas about secular money wage stickiness, perhaps descended from Marshall, had come to play a key role in macroeconomics and underlay the idea that inflation was largely a matter of exogenous "wage-push"; and, that, in the ensuing debate, what was characterized as "wage-price flexibility" would, from the later perspective of New-classical economics better be termed "wage-price stickiness".

This lecture's implications for the interpretation of modern macroeconomics can, therefore, be summarized as follows. If the criterion is the treatment of money wage and price 
flexibility, then New-classical economics is new, but it is surely not Classical; and NewKeynesian economics is neither new nor distinctively Keynesian. Moreover, there is nothing inherently "easy" about understanding the effects of wage and price stickiness. If it is now trivially obvious that their presence in an economy implies that real variables will fluctuate, this is only because economics has taken about 250 years to work out how such effects are brought about.

\section{II}

\section{WAGE-PRICE STICKINESS IN CLASSICAL ECONOMICS}

By "Classical Economics" I mean that body of economic thought which begins with Cantillon and Hume, ends with Mill, who died in 1873, and in addition to them includes among the most distinguished contributors to its monetary analysis Adam Smith, David Ricardo and of course, Henry Thornton. I shall apply the adjective "Neo-classical" to the economics of Marshall, Pigou, Wicksell and their contemporaries, though, confusingly, it was this later body of doctrine that Keynes had in mind when he launched his assault on "Classical" economics. The main focus of Classical economics as I define it here was, on the real side, growth, distribution and allocation; and on the monetary side, the price level, the balance of payments and the exchange rate, banking and central banking. The business cycle is conspicuously absent from the above list. Although Classical economists from Henry Thornton (1802) onwards were well aware of, and wrote extensively about, financial crises, recognition that such crises were but one phase in a repetitive pattern of economic fluctuations came towards the end of the Classical period -- roughly speaking during the two middle quarters of the 19th century; and understanding that such fluctuations involved real magnitudes such as output and employment as 
well financial variables came even later. Even for those Classical economists who discussed it explicitly, the cycle was the "credit cycle", not the "trade", or "business" cycle.

It is hardly surprising that explicit statements, to the effect that sticky money wages were crucial in transforming fluctuations in what we would now call aggregate demand into fluctuations in real income and employment, are few and far between in the Classical literature; but they can be found. The best known of them is in Thornton's (1802) Paper Credit:

\begin{abstract}
"But a fall [in prices] arising from temporary distress, will be attended probably with no correspondent fall in the rate of wages; for the fall of price, the distress, will be understood to be temporary, and the rate of wages, we know, is not so variable as the price of goods. There is reason, therefore, to fear that the unnatural and extraordinarily low price arising from some sort of distress of which we now speak, would occasion much discouragement of the fabrication of manufactures." (p. 118)
\end{abstract}

These words occur in a striking passage in which Thornton distinguishes between permanent and transitory shocks, suggests that transactions costs make wages sticky in the face of the latter, and attributes output and employment effects to this fact. It clearly describes a mechanism tailor-made for inclusion in a model of the cycle, and indeed in the 1980s, Brunner, Cukierman and Meltzer (1983) did just that. ${ }^{1}$ But that is not how Thornton deployed it. Rather, the above quotation arises in the context of his discussion of the appropriateness of the Bank of England meeting downward pressure on the then floating sterling exchange rate with a monetary contraction; and its argument is used to defend the claim that, in the face of a temporary deficit, caused say by a poor harvest, such contraction would be both unwise and perhaps even counterproductive. The disruption to output that it would create would, according to Thornton, simply compound the difficulties created by the initial shock, which left to themselves would in any 
event be temporary.

This argument of Thornton's was criticised by Ricardo, who regarded any balance of payments deficit or exchange depreciation, permanent or transitory, as prima facie evidence of an excess money supply, and hence requiring its reduction. Thornton seems, in due course, to have accepted this criticism. ${ }^{2}$ In 1810, he was an important contributor to the Bullion Report (see Cannan (1919)), which among other things, criticised the Bank of England for failing to contract its issues when the 1808 French blockade of North Germany (surely a transitory shock) drove down the exchange rate, and recommended a speedy restoration of gold convertibility at the parity ruling in 1797 when convertibility had been suspended, a measure which in 1810 would have required an immediate and significant cut in money prices and wages. Thornton, then, was no prototype "Keynesian" economist, old or new, and yet it would be a mistake to infer from the foregoing account that Classical economists were usually inclined to reject the wage-price stickiness postulate. On the contrary, in certain contexts they appear to have taken it for granted, albeit without being entirely self-conscious and explicit about doing so, and therefore without drawing out its full implications for the economy's functioning.

As early as (1752) Hume, perhaps building upon the foundations laid by Cantillon (1734) (though there is no explicit evidence that Hume was aware of his predecessor's work) had set out the basic framework of Classical monetary theory. In a well known and much quoted passage dealing with what we would now call the transmission mechanism whereby a change in the quantity of money affects the level of prices, he noted:

"...though the high price of commodities be a necessary consequence of the increase of gold and silver, yet it follows not immediately upon that increase... At first no alteration is perceived; by degrees the price rises, first of one commodity, then 
of another, till the whole at last reaches a just proportion with a new quantity of specie which is in the Kingdom. In my opinion, it is only in this interval or intermediate situation, between the acquisition of money and rise of prices, that the increase of gold and silver is favourable to industry...we shall find, that it must first quicken the diligence of every individual, before it increases the price of labour." (p. 293)

Furthermore

"...this interval is as pernicious to industry when gold and silver are diminishing, as it is advantageous when metals are increasing. The workman has not the same employment...though he pays the same price for everything in the market. The farmer cannot dispose of his corn and cattle, though he must pay the same rent to his landlord. The poverty and beggary, and sloth, which must ensue are easily foreseen." (p. 296)

These passages tell us that time elapses between a monetary impulse and the response of money wages and/or prices, and that in the interim, quantities move instead. Such a non-instantaneous response is precisely what we nowadays mean by "stickiness"; and this idea of Hume's in due course entered the Classical mainstream. ${ }^{3}$

Adam Smith, being concerned in the monetary analysis contained in the Wealth of Nations (1776) with the long run beneficial effects on an economy's capital stock of replacing commodity money with paper, did not discuss short-run adjustment problems; but Ricardo, universally regarded as the epitome of Classical orthodoxy in matters of monetary theory, and who seems to have persuaded Thornton to abandon a policy position that hinged on the postulate of wage stickiness in the face of a temporary disturbance, nevertheless did. His (1816) "Proposal for an Economical and Secure Currency" urged the creation of a monetary system based, not on gold coin, but on paper convertible on demand into bullion, albeit at the 1797 
parity, and he defended this proposal on two grounds. First it would economise on precious metals and hence, as Smith had argued, permit the country to enjoy a larger capital stock; and second it would minimise the demand for gold and therefore the amount of price deflation needed to restore sterling to its 1797 parity. ${ }^{4}$ This second argument was completely in the spirit of Ricardo's view that there was a limit to the speed with which nominal prices could be forced downwards, as implied, for example, in his observation of (1810-11):

"The remedy which I propose for all the evils in our currency, is that the Bank [of England] should gradually decrease the amount of their notes until...the prices of gold and silver bullion shall be brought down to their mint price...its sudden limitation would occasion so much ruin and distress... If gradually done, little inconvenience would be felt." (p. 96)

The Humean idea that money wages and prices did not adjust instantaneously to the money supply, so that monetary changes had real short-term consequences is also expressed in several passages in Mill's Principles, but not when he discussed the credit cycle. However an apparently separate phenomenon, which Mill did describe in the context of the cycle, also requires a failure of prices to move sufficiently quickly to keep markets cleared if it is to occur. I refer to his analysis, first presented in an 1829 essay (not published until 1844) but also incorporated into the Principles, of how a general glut of commodities can occur at the crisis phase of what he called the credit cycle as a complement to an excess demand for money. The essential insight underlying this analysis is captured in the following quotations from these two sources.

\footnotetext{
"But those who have, at periods such as we have described, affirmed that there was an excess of all commodities, never pretended that money was one of those commodities; they held
} 
that there was not an excess, but a deficiency of the circulating medium. What they called a general superabundance, was not a superabundance of commodities relatively to commodities, but...relatively to money...the result is, that all commodities fall in price, or become unsaleable." (1844, pp. 71-72)

"At such times there is really an excess of all commodities above the money demand..." (1871, p. 574)

Now Mill most assuredly did not postulate price rigidity here; on the contrary, falling commodity prices were of the very essence of a financial crisis as far as he was concerned, but the fact remains that in an economy in which prices were sufficiently malleable to maintain supply equal to demand in all markets, the temporary excess demand for money and matching glut of commodities described in the foregoing passages could not arise.

The point of all this is not that Classical economics had a well worked out view of how the economy functioned, in which postulates about money wage and price stickiness played a central and clearly defined role. Neither the fragments of the Classical literature which I have quoted, nor anything else in it of which I am aware, could support such a claim. However, the nominal stickiness idea did make frequent appearances in that literature, inasmuch as that certain ideas universally agreed to have been central to Classical monetary theory, specifically those about the short run non-neutrality of money, do not make sense unless we interpret their exponents as having taken it for granted that money wages and prices fail to move fast enough to keep markets continuously cleared. And the same may be said of the much less frequent references to the possibility of a general glut of commodities arising during a financial crisis. The interconnectedness of these phenomena, and their relationship to cyclical fluctuations, was not, however, to be fully worked out until the 1960 s. Neo-classical economists began this process; Keynes contributed to it, but it needed Haberler, Pigou and Patinkin not to mention 
Phelps and Friedman to complete it.

\section{III}

\section{NEO-CLASSICAL CONTRIBUTIONS}

The passages of Mill referred to above are well known as early, though far from complete, descriptions of the real balance effect at work. As Becker and Baumol (1954), later documented, such descriptions became rather common in the literature of Neo-classical economics as the 19th century drew to a close. Sometimes they dealt with falling and sometimes with rising prices, and the following much quoted passage from Wicksell (1915) is notable for clarity and incisiveness, but not uniqueness:

"A general rise in prices is...only conceivable on the supposition that the general demand has for some reason become, or is expected to become, greater than the supply. This may sound paradoxical because we have accustomed ourselves, with J.B. Say, to regard goods themselves as reciprocally constituting and limiting the demand for each other. And indeed ultimately they do so; here, however, we are concerned with precisely what occurs, in the first place, with the middle link in the final exchange of one good against another, which is formed by the demand of money for goods and the supply of goods against money." (p. 159, italics in original)

This passage displays a clear and explicit understanding that, for a change in the quantity of money to affect the price level, it must first create a disequilibrium situation in which Say's law does not hold, that is to say a state of affairs in which markets are not cleared. It is paradoxical, therefore, that neither Wicksell, nor Irving Fisher, who was every bit as clear about these matters (see (1911), pp. 153-154), did not, in their pre-World War I writings, go on to associate such a failure of markets to clear with the occurrence of output and employment 
variations, even in the case of monetary contraction.

When Wicksell analysed his celebrated cumulative inflationary process in the case of a "pure credit" economy, in which there could not exist an excess supply of "money" -- in his vocabulary synonymous with "currency" -- for the simple reason that money did not exist, he did so in terms of a model which the labour and output markets cleared, sequentially rather than simultaneously to be sure, but cleared nevertheless. Though the model in question contained a sticky price, this was the nominal rate of interest, not the money wage or money price level; and the failure of the capital market to function smoothly had its real effect on the distribution of profits between entrepreneurs and capitalists, not on the overall levels of employment and output. Similarly, Fisher (1911, Ch. 4), whose cycle theory depended on interest rate stickiness and a failure of the loans market to remain in equilibrium following an initial shock, explicitly referred to the cycle as a phenomenon of rising and falling prices, not rising and falling output. ${ }^{5}$ Neither Wicksell nor Fisher even raised the question of how a condition of general excess demand or supply of goods might affect the output and labour demand decisions of producers, let alone attempted an answer to it.

One important strand of Neo-classical economics, that developed at Cambridge, was selfconscious about money wage stickiness however, and did attempt to investigate its consequences for income and employment. The focus here, however, was not the real balance effect, but the consequences for real wages of the interaction of flexible prices and sticky money wages. In (1879) Alfred and Mary Marshall gave an account of the cycle, which closely followed that of Mill, but extended it with the comment, "The connexion [sic] between a fall in prices and a suspension of industry requires to be further worked out" (p. 155). Their solution to this problem was as follows: 
"It...very seldom happens...that the expenses which a manufacturer has to pay out fall as much in proportion as the price which he gets for his goods. For when prices are rising, the rise in the price of the finished commodity is generally more rapid than that in the price of the raw material, always more rapid that in the price of labour; and when prices are falling, the fall in the price of the finished commodity is generally more rapid than that in the price of the raw material, always more rapid than that in the price of labour." (p. 156)

Money wage stickiness is invoked here as an apparently self-evident fact of life, and not as a tentative hypothesis in need of theoretical defence or empirical justification. It is hard to believe that the Marshalls thought their observations concerning its existence controversial, and no evidence of which I am aware in the subsequent literature suggests that anyone else found it so. And indeed, if we turn to that slightly earlier classic of empirical monetary economics, Jevons' (1863) "Serious Fall in the Value of Gold..." we find the following:

"In a large proportion of cases, the salaries of clerks, officials, and other employes, or the wages of servants and labourers, will remain unchanged for long periods of time by want of attention to the changed value of gold, or the general dislike to altering or discussing an agreement once made...the salary or wage will be raised after the lapse of a certain time." (p. 85)

Money illusion and the costs of contracting are here invoked by Jevons, and the context of the discussion makes it clear that he was self-consciously aware of both phenomena. He discussed strikes as a manifestation of the former, and the main thrust of the pamphlet from which the above quotation is taken was to demonstrate, with the use of newly developed price indices, that stability in the purchasing power of money, widely taken for granted among his contemporaries, ought not to be. And once introduced into the literature, these ideas stayed there. They were deployed, for example, by Pigou in his (1913) book on Unemployment, a work aimed not at 
academics, but like others in the Home University Library series in which it was published, at a lay readership.

All in all, I think it is safe to conclude that money wage stickiness was a phenomenon widely taken for granted in Britain in the late 19th and early 20th century, and that the Marshalls' originality lay, not so much in postulating it, but in recognising its potential relevance to the explanation of output and employment fluctuations as integral features of the cycle. It was to become a staple, though not always central, ingredient of British discussions of these matters for the next century. Hawtrey, Robertson, Pigou, Hayek, and Robbins, among others, all at various times cited money wage stickiness as one of the reasons why the downswing of the cycle brought with it not merely falling prices, but falling output and employment too. ${ }^{6}$

However, until the development of multiplier-accelerator theory, which did not begin until the late 1930s, cycle theorists concentrated on explaining the boom and crisis phases of the cycle; downswing and slump were regarded as the inevitable aftermath of these and seldom analysed with as much care: Marshall's evidence to the Indian Currency Committee of 1899 is typical of this sort of treatment.

"...a sudden fall of prices, presses hardly on business enterprise of all kinds. It is likely to make many employers fail, and generally interrupt industry... Such a fall of prices is an almost unmixed injury to the employee as it is to the employer. Such a fall of prices...is nearly always, if not always, the result of a previous inflation of prices and launching of frail enterprises by fraudulent or incompetent people who have floated into prosperity at the cost of others on the top of the wave of rising prices." $(1926$, p. 285)

Hence though sticky money wages were much cited by British Neo-classical economists and 
blamed by them for cyclical unemployment, the explanation offered as to why seldom got beyond that initially offered by the Marshalls in 1879 , namely that the interaction of flexible output prices with sticky money wages induced a perverse countercyclical movement into the time path of real wages. One exception here is Hawtrey, who as early as (1913) not only discussed the effects of money wage stickiness on the behaviour of real wages, but also (1913, p. 65) pointed out that stickiness of money wages would prevent money prices falling as fast as they otherwise might. This latter mechanism is of course crucial to ensuring that the consequent effect on real balances works only slowly on the demand for output. Hawtrey was aware of this connection, but his appreciation of its implications was far from complete. The matter did attract more attention later, as we shall see, but not until The General Theory had shifted the centre of attention from supply side to demand side considerations.

Marshall also discussed secular, as opposed to cyclical, money-wage stickiness on a number of occasions. His evidence to both the Gold and Silver Commission of 1888-89 and the Indian Currency Committee of 1899 (reprinted in Marshall (1926)) on the relative merits of a secularly rising, stable, or falling price level, saw him citing as an advantage of the last of these the fact that it would induce a long-term increase in real wages; nor did Marshall discuss any adverse effects on employment in this context. His discussions of the cyclical and secular consequences of wage stickiness were thus, in strict logic, inconsistent. I conjecture that we should reconcile them by attributing to Marshall the view that relatively small and slow-moving secular price level induced changes in real wages would go unnoticed by participants in the labour market, as more violent cyclical fluctuations would not. Marshall did, after all, warn readers of his Principles that, with regard to the labour market: 
"...it is...important to insist that we do not assume for members of any industrial group to be endowed with more ability and forethought, or to be governed by motives other than those which are in fact normal to, and would be attributed by every wellinformed person to, the members of that group..." (8th ed., p. 448)

Whatever his reasons for holding it, however, Marshall's idea that the secular time path of money wages could (perhaps within limits) be treated as given and independent of that of prices, was later to become important.

\section{IV}

\section{WAGE STICKINESS AND THE THEORY OF EMPLOYMENT}

The discussions of money wage and price stickiness dealt with in the preceding section of this paper were unsatisfactory by modern standards, and indeed perfunctory by contemporary standards too. It was only as the 1920 s progressed that, in Britain at least, economists began to conclude that large scale unemployment presented theoretical problems worth analyzing in their own right, rather than being simply an inevitable and unfortunate, but nevertheless temporary, consequence of war-time and immediate post-war inflationary booms. ${ }^{7}$ To many British economists, unemployment in the interwar years appeared to be a secular phenomenon, not in the modern sense of requiring analysis in the context of a model of economic growth, but in a looser sense, which has no exact parallel in our current vocabulary, of persisting for longer than a single cycle and therefore requiring tools over and above those provided by cycle theory for its understanding. That is why, for example, Pigou regarded his (1933) Theory of Unemployment as a complement to his (1927) Industrial Fluctuations, rather than as being in any way a substitute for the earlier work. 
And as unemployment was discussed more frequently, so was too high a real wage level induced by money-wage stickiness as its cause, and policies designed to bring about wage flexibility as its cure. In Britain the importance of analyzing the interaction of money wages, real wages and employment was enhanced by the price deflation required by the 1925 restoration of the gold convertibility of sterling at the 1914 parity. Virtually all contemporary commentators on this measure, supporters as well as opponents, agreed that the key to its success would lie in securing money wage cuts and that this would be a painful process; disagreement about its wisdom hinged on judgements about just how difficult this would be, and on whether the restoration of the old parity would bring enough benefits to justify the hardship it would inevitably cause. ${ }^{8}$

Pigou's (1933) Theory of Unemployment provides the fullest account of what Keynes was, in the General Theory, to call the "Classical" (but which this paper would call Neoclassical) theory of unemployment. Keynes was correct to single this book out for discussion in (1936) though he was also brutally unfair in the account he gave of its content.9 Pigou deployed a standard Marshallian apparatus in which, with a given capital stock, the interaction of the supply and demand functions for labour determine equilibrium employment and the real wage. Unemployment, as Pigou used the word, can only arise in such a framework if the real wage is above its equilibrium level. Pigou was explicit that wage bargaining was proximately about money wages, but the analytic tools he utilised forced him to treat real, rather than money, wage stickiness as the basic phenomenon in need of explanation. Though he still pointed out that the money-illusion induced money wage stickiness of which he had made much in his earlier (1913, p. 115 et. seq.) discussion of cyclical unemployment exacerbated real wage stickiness, Pigou did not, in 1933, think that this was by any means the whole story. 
Furthermore, the question about the effects of a cut in real wages which he addressed was not whether such a policy would influence employment -- he took it for granted that it would -- but how large that influence would be. As to cuts in money wages as a cure for unemployment, the main question Pigou addressed was how big an effect on real wages, and hence on the demand for labour, they would have.

In (1936, Ch. 19, Appendix) Keynes accused Pigou of implicitly and unwittingly assuming full employment throughout his analysis; but this charge was unfair. On the contrary, Pigou was careful and explicit about avoiding this particular trap. He considered the possibility that a cut in money wages would lead to an equiproportional fall in prices, and leave the real wage, and therefore, according to his model, output and employment unchanged, and he rejected it on the grounds that, to obtain an equiproportional fall in prices, one would have to begin by assuming constant output and employment.

"The conclusion we have reached...describes what would happen if money wage-rates were reduced and if the quantity of employment remained unaltered. The idea sometimes entertained that, by means of it, we can prove that the quantity of employment, and therewith the real rate of wages, will remain unaltered is completely fallacious. The answer is assumed before the argument has begun." (p. 101, italics in original)

In Pigou's view, the effect of a cut in money wages on money prices would depend on the degree of openness of the economy and on the operation of the monetary system. He argued explicitly, for example, that, in the limiting case of a small price taking open economy, the price level would be given exogenously, so that a money wage cut would bring about an equiproportional real wage cut. In the polar opposite limiting case of a closed economy, he made the operating assumption that the monetary authorities would act so as to maintain the 
level of money income constant. On that assumption a fall in the price level would have to be offset by an increase in output. Therefore, the price fall in question would be less than proportional to that in money wages, the real wage would be reduced, and the quantity of labour demanded would increase. In all cases, whether the economy was open or closed, it was on the supply side response triggered by the effect on real wages of a cut in money wages that Pigou concentrated. As an empirical matter, he believed that the effect of a money wage cut on employment would be significant in contemporary Britain.

"...in times of deep depression, after an interval not less than the period of production of the generality of wage-goods and export goods, an all round cut of 10 per cent in money rates of wages would lead, other things being equal, to a more than 10 per cent expansion in the aggregate volume of labour demanded, and so, apart from unfilled vacancies, in the volume of employment..." (p. 106, italics in original)

Logically speaking, Pigou's assumption, in the closed economy case, that money income was held constant by the monetary authorities produces a limiting "vertical LM-curve" version of a by now rather standard, indeed old fashioned, macro model, whose more general form can capture all the demand side influences of a money wage cut to which Keynes later pointed -- those operating "...on the propensity to consume for the community as a whole, or on the schedule of the marginal efficiency of capital, or on the rate of interest" (1936, p. 262). This was not apparent in 1933 or indeed in 1936, however. Keynes believed his treatment of aggregate demand to be quite different from any that used the quantity theory, rather than, as we now understand, a more general formulation of the same analysis. ${ }^{10}$ Though hindsight enables us to see that the effect of a price level fall on the quantity of real balances must underlie Pigou's (1933) deployment of the quantity theory to close the demand side of his system, this 
was not apparent to anyone in 1936 either, least of all Pigou, who did not incorporate such effects into his analysis until his (1938) response to Kaldor's (1937) criticisms. In this exchange, Kaldor argued, correctly, that Pigou had earlier overemphasized the significance of money wage cuts for the real wage, and correspondingly underemphasized their influence on the price level and hence on the real quantity of money; and Pigou accepted both points.

Keynes' major contribution to the theory of unemployment was to shift the centre of attention from the supply to the demand side of the aggregate economy. He accepted and paid attention to the same demand curve for labour as a function of the real wage which Pigou had analysed in excruciating detail -- but his treatment of the economy's supply side was almost as perfunctory as had been Pigou's of the demand side. What principally mattered for Keynes was not what a cut in money wages would do to real wages, but rather what indirect effect its influence on prices would subsequently have on aggregate demand; and since he believed this effect to be minor and unreliable he did not attach great importance to money wage stickiness as a cause of low real income and employment. For Pigou (before 1938) as for other Neo-classical economists, money wage cuts of sufficient magnitude were a sure cure for unemployment, whose principal cause was too high a level of real wages. For Keynes, they would be of dubious benefit in dealing with a problem at whose heart lay a deficiency of aggregate demand.

A "policy of wage flexibility" had serious drawbacks in Keynes' view:

"It is...on the effect of a falling wage- and price-level on the demand for money that those who believe in the self-adjusting quality of the economic system must rest the weight of their argument...if the quantity of money is virtually fixed, it is evident that its quantity in terms of wage units can be indefinitely increased by a sufficient reduction in money-wages...

We can...theoretically at least, produce precisely the same effects on the rate of interest by reducing wages, whilst leaving 
the quantity of money unchanged, that we can produce by increasing the quantity of money whilst leaving the level of wages unchanged... Just as a moderate increase in the quantity of money may exert an inadequate influence over the long-term rate of interest, whilst an immoderate increase may offset its other advantages by its disturbing effect on confidence; so a moderate reduction in money-wages may prove inadequate, whilst an immoderate reduction might shatter confidence even if it were practicable.

There is, therefore, no ground for the belief that a flexible wage policy is capable of maintaining a state of continuous full employment; ...the economic system cannot be made self-adjusting along these lines." (pp. 266-267)

Besides

"To suppose that a flexible wage policy is a right and proper adjunct of a system which on the whole is one of laissez-faire, is the opposite of the truth. It is only in a highly authoritarian society, where sudden, substantial, all-round changes could be decreed that a flexible wage policy could function with success." (p. 269)

Hence, Keynes did not recommend such a policy. Far better, he thought, to concentrate on increasing aggregate demand by other means, and to rely on a rising price level to induce the real wage fall that would permit the economy's supply side to respond.

Whether Keynes assumed money-wage stickiness or not is sometimes debated. On this evidence, he took it for granted as a fact of life - that is why wage flexibility was termed "a policy", involving the taking of measures to overcome a property of the labour market. But surely the question is of minor relevance to understanding Keynes' intended contribution. In the first 18 chapters of The General Theory, he held money wages constant, not because he thought that the assumption was crucial to his results, but because as he explained in Chapter 19, he thought that money wage fluctuations were a factor that complicated his analysis without 
changing its basic characteristics. And one implication of his analysis was that money wage fluctuations mainly affected employment indirectly, through prices and thence aggregate demand, rather than directly through the real wage.

When Haberler, (1939) Pigou (1943, 1947), and Patinkin (1948, 1956), came to reassert the analytic correctness of the proposition that, in the absence of complete money wage rigidity, a market economy tends to converge on a full employment equilibrium -- a proposition usually termed "Classical", they did not also reassert the central importance of real wage behaviour on the economy's supply side for its validity. Rather, they took up, and elaborated on Keynes' transmission mechanism which worked through aggregate demand. ${ }^{11}$ Keynes had conceded the possibility of falling money wages, and hence prices, driving down the rate of interest. To this channel, Haberler and Pigou added a direct wealth effect working through the changing real value of nominal assets; while in (1948) Patinkin synthesized these mechanisms, and later in (1956) refined the relevant analysis by investigating the micro foundations of the real-balance effect. Classical economics had, as we have seen, developed the analysis of the latter effect, but its clearest exponents, Wicksell and Fisher, had not associated cash balance mechanics with variations in income and employment. It required Keynes's explicit application of aggregate demand analysis to the problem of unemployment to enable this all important link to be made. As Patinkin (1948) put it,
"Although both Pigou [writing in (1943) and (1947)] and the "classics" stress the importance of "price flexibility", they mean by this term completely different things... The classical school holds that the existence of long-run unemployment is prima facie evidence of rigid wages. The only way to eliminate unemployment is, then, by reducing real wages... Pigou now [i.e. in (1943) and (1947)] recognizes that changing the relative price of labour is not enough, and that the absolute price level itself 
must vary." (p. 265, italics in original)

This analysis nevertheless seemed to many, at the time of its publication, to be profoundly anti-Keynesian, even though its exponents were careful to avoid claims of any policy significance for this analysis. Thus Pigou in (1947):

"...the puzzles we have been considering...are academic exercises, of some slight use for clarifying thought, but with very little chance of ever being posed on the chequer board of actual life." (p. 251)

and Patinkin in (1948):

"The conclusions of this paper can be summarised as follows: in a static world with a constant stock of money, price flexibility assures full employment... But in the real dynamic world in which we live, price flexibility with a constant stock of money might generate full employment only after a long period; or might even lead to a deflationary spiral of continuous unemployment. On either of these grounds, a full employment policy based on a constant stock of money and price flexibility does not seem to be very promising." (pp. 277-278)

But the fact remained that Keynes had claimed to have created a theory of unemployment equilibrium. He had also, in Chapter 19, of the General Theory denied that money wage flexibility would inexorably lead to full employment, and he based this claim on theoretical, not empirical arguments. Thus, Keynes's position was to deny any overriding importance to wage stickiness in determining the way in which the economy functioned; and the exponents of what we now know as the "Neo-classical Synthesis" gave a much more important role to the phenomenon. Even so -- following Pigou and Patinkin -- those exponents denied that their analysis of this matter was policy relevant, precisely because of an empirical judgement to the 
effect that money wages were, if not rigid, then certainly sticky enough to render the working of the economy's self-correcting mechanisms unacceptably slow.

\section{$\mathbf{V}$}

\section{THE PHILLIPS CURVE AND AFTER}

The adjustment mechanism underlying the real balance effect has the money wage rate falling in the presence of high unemployment. It is a small step, but a distinct one nevertheless, from this observation to the proposition that the rate of change of the money wage rate is an inverse function of the unemployment rate. Perhaps not entirely coincidentally, Pigou had presented a time series chart showing just such an inverse relationship in Industrial Fluctuations (1927, p. 215), but it was not until the work of Brown (1955), Phillips (1958) and Lipsey (1960) that the so-called "Phillips Curve" attracted much attention. Phillips, and with more elaborate analysis Lipsey, presented the Phillips Curve as a by-product of a standard supply and demand stability experiment applied to the labour market, with unemployment standing as a proxy variable for the excess demand for labour, but before Phelps (1967) and Friedman (1968) offered their well known extension of his analysis -- based on the simple observation that the supply and demand for labour determine the real, not the money wage -- the construct was controversial for another reason, which we must now discuss.

We have seen earlier that Marshall had treated money wage stickiness as a secular, as well as a cyclical phenomenon in the 1880 s and 1890 s. In the 1930 s, a version of this hypotheses again became current. The very fact that such commentators as Pigou (1933) and Keynes (1936) treated unemployment as long-term problem, significant beyond the confines of the cycle, and discussed money wage stickiness in this context, is evidence of this. And some 
writers were quite explicit about the matter. For example, Myrdal (1931) in discussing the appropriate price level behaviour for the authorities to aim at usually made the assumption that "...the prices of the basic factors of production are the principal sticky prices...practically, this means an assumption that wages are relatively sticky prices..." (p. 139). ${ }^{12} \mathrm{He}$ also found it instructive to analyse the policy problems posed to a monetary authority in the limiting case where the presence of one-sided monopoly in the labour market ensured that "...the workers would not become unemployed as a result of their monopolistic wage increase..." so that "...a general process of rising prices accompanies ['a self-generating movement caused by monopolistic activity of the sticky and therefore dominant prices']" (p. 148). In such circumstances, according to Myrdal, the appropriate aim for monetary policy would be to "adapt the flexible prices to the sticky ones" (p. 133, italics in original).

By the post-war period, the idea of a secularly sticky money wage to whose time path policy should be adapted had evolved into the notion that the time path of the variable in question was institutionally (perhaps politically), determined. In 1955, for example, Sir John Hicks argued as follows: ${ }^{13}$

\footnotetext{
"But the world we now live in is one in which the monetary system has become relatively elastic, so that it can accommodate itself to changes in wages, rather than the other way about... It is hardly an exaggeration to say that instead of being on a Gold Standard, we are on a Labour Standard." (p. 196)
}

In some versions of this kind of argument, the behaviour of wages was quite independent of market forces; and more generally, the view that inflation was mainly a phenomenon of "wagepush" became dominant in Britain, and very popular elsewhere.

The Phillips curve had it that, unless the unemployment rate was at some equilibrium 
level determined by structural and frictional forces, money wages would move in a fashion calculated to restore that equilibrium (see Figure 1). Hence it ran counter to the secularly sticky money wage hypotheses, and seemed at the time, to be supported by a great deal of empirical evidence too. However, the mainstream response to this challenge was not to abandon the idea that the time path of money wages was independent of market forces, but to concede, as indeed had Hicks, that the pressure of demand, could modify the extent to which institutionally conditioned secular money wage behavior would assert itself. The views expressed by the Radcliffe Report (1959) are quite representative

"It is sometimes argued that the rate of rise of wage rates is very closely related with the percentage of unemployment. But it has also been argued to us with no less authority and force that over a significant range of variations in the demand for labour there is a 'band of indeterminacy' within which the precise rate at which wage rates and prices rise depends upon institutional factors which...have little or no connection with the pressure of demand... All that can be assessed as agreed opinion is that, as the fullness of full employment rises, the risk of accentuating a rise of prices increases." (p. 21)

This is not the place for a long digression into debates about institutionally-determined "cost-push" inflation, and the role of the Phillips curve therein. What matters for the topic at hand is simply that "cost-push" advocates sometimes argued that the money wage rate's time path was at least insensitive, and at most utterly impervious, to market forces; while on the other side, those who believed in the Phillips curve argued that it would always move in response to excess demand or supply in the labour market, as proxied by the unemployment rate, in a manner summarized by that curve. Debate was, therefore, between those who believed money wages to be essentially rigid, and those who thought of them as being merely sticky. 
The possibility of money wages being sufficiently flexible as to keep the labour market perpetually cleared was never raised, let alone discussed.

As I remarked earlier, Phillips and Lipsey's theoretical underpinnings for the Phillips curve were soon challenged by Phelps and Friedman, who noted that the relevant price in the labour market was the real, not the money wage. As Friedman put it
"Phillips' analysis of the relation between unemployment and wage change is...an important and original contribution. But, unfortunately, it contains a basic defect -- the failure to distinguish between nominal wages and real wages... Implicitly, Phillips wrote his article for a world in which everyone anticipated that nominal prices would be stable..." (p. 102, italics in original)

Now theoretical analysis of the influence of the price level on real aggregate demand, such as that of Haberler, Pigou and Patinkin, was invariably carried out in terms of a model in which the nominal money supply was held constant and in which therefore such an assumption about agents' anticipations was reasonable. But in the early 1960 s the Phillips curve had begun to be treated as a policy relevant structural relationship whose form was independent of the conduct of monetary policy; and by the early 1970 s, it had ceased to exist as an empirical phenomenon.

For those who would soon come to be labelled Monetarists, the expectations augmented Phillips Curve of Phelps and Friedman provided a ready made response to this new empirical evidence; but for British Monetarists, at least, the addition of expected inflation to its right-hand side, so that there existed a family of curves in wage inflation-unemployment space, one for every value of the expected rate of price inflation (see Figure 2), did not mean that it had ceased to characterise a labour market which could be out of equilibrium in the short run; and out of equilibrium not just in the sense that the actual price level could differ from that expected 
or perceived by those involved in wage bargaining, but also, crucially, because given expected and actual values of money wages and prices, the supply and demand for labour could differ from one another. My own (1971) account of the matter went as follows:

"If the excess demand for labour is inversely related to the level of unemployment and positively related to the rate of change of the real wage, then...there will exist a stable inverse relationship between the rate of change of real wages and the level of unemployment...to get to the Phillips curve we must introduce the expected rate of price inflation into our model.

We need the expected rate of inflation and not its actual current rate because individual wage bargains are struck at discrete intervals and, for any particular bargain, it is not the current price level that matters in determining the real wage that is being aimed at but the level of prices that is expected to rule over the period for which the bargain is being struck." (pp. 79-80, italics in original)

In treating the short-run Phillips Curve as describing disequilibrium wage adjustment, this analysis, for which I make no claim of originality, was much like that of American Keynesians such as Robert Solow (1969) and James Tobin (1973). Differences of opinion here were about whether expectations of price level behaviour held by participants in the labour market would, in conditions of mild inflation, ever fully adjust to reality; and hence about whether the long run Phillips Curve was vertical (as it has been drawn in Figure 2), or merely "steep". Ironically, in their belief that the long-run curve still had a negative slope, American Keynesians were perhaps truer intellectual descendants of Marshall than were their Monetarist contemporaries (which is not to say that they were right). In the 1880 s and 1890 s, Marshall had, as we have seen, argued that secularly falling prices would leave money wages unaffected, and in the long run, produce a permanent increase in real wages. This aspect of the monetarist debate was, on the whole, settled in favour of those who denied the existence of any long-run 
inflation-unemployment tradeoff, and during the 1970s macroeconomists found newer, and to that extent at least more interesting, matters to argue about.

At first the major novelty of New-classical economics seemed to lie in its deployment of John Muth's (1961) rational expectations hypothesis to replace the error learning mechanism in models of inflation-unemployment interaction: who after all could resist the idea that rational agents would make "full" use of "all available" information? It is by now recognized, however, that its adoption of the assumption that all markets are continuously cleared by flexible prices, and its reconciliation of this assumption with the existence of variations in real variables such as income and employment (neither of which steps logically depended upon assuming rational expectations), represented far more profound analytic innovations; and yet the innovations in question slipped into the literature almost unnoticed. It was a simple matter to include the expected price level as a variable in an aggregate supply curve of a type that Marshall, Pigou, (or indeed Keynes) would have understood, and, by simple algebraic manipulation, to produce a relationship apparently identical to a conventional expectations augmented Phillips curve. This much was implied by Friedman's ambiguous (1968) analysis, and was shown explicitly by a number of contributors to the so-called "Phelps Volume" (Phelps et al.(1970)). ${ }^{14}$

Once the possibility had been broached that the expectations augmented Phillips curve was a particular transformation of an aggregate supply curve, and hence of a demand function for labour depending on the real wage, the way was open to explain the values of output, employment, wages and prices as the solutions to the equations characterising a simple general equilibrium model. To take this apparently purely technical step, however, was to make a very important substantive assumption as well, namely that money wages and prices could always move freely to keep all markets cleared; though I strongly suspect that this radical departure 
from earlier ways of doing macroeconomics owed more to the unselfconscious application to a new set of problems of standard analytic techniques, involving formulating an economic model as a set of simultaneous equations and deriving its predictions as those equations' solutions, than it did to any conscious attempt to create a revolution in economic thought.

The analytic techniques were, of course, those of Walrasian general equilibrium analysis, which by the 1970s had largely driven Marshallian partial equilibrium tools out of microeconomic theory, and it is instructive to consider Walras' own opinion of the empirical relevance of the idea of general economic equilibrium. As is readily apparent from the following passage, Walras (1874) shared the views of his contemporaries on the relative stickiness of input prices. Hence, he regarded a state of general equilibrium in which supply equals demand in each market as defining a hypothetical benchmark around which the economy fluctuates, and not a condition which holds at each and every moment. Indeed, in expressing this view at such an early date, he anticipated some aspects of the Marshalls' analysis of the cyclical significance of money wage stickiness discussed earlier.

"...the market is like a lake agitated by the wind, where the water is incessantly seeking its level without ever reaching it. But whereas there are days when the surface of the lake is almost smooth, there never is a day when effective demand for products and services equals their effective supply... It...frequently does happen in the real world, that...the selling price will remain for long periods of time above cost of production... while under other circumstances a fall in price... will suddenly bring the selling price below cost of production and force the entrepreneurs to reverse their production policies. For, just as a lake is, at times, stirred to its very depth by a storm, so also the market is sometimes thrown into violent confusion by crises, which are sudden and general disturbances of equilibrium." (p. 380-381, italics in original)

Now it is important to distinguish between "good" economics, and "correct" (better say 
"not-yet-refuted") economics. The former predicts much from little, and the latter, in addition, finds that what it predicts seems to occur. In these terms, New-classical economics was most assuredly good economics. The trouble was (and is) that its distinguishing predictions were inconsistent with the facts and that, as Karl Brunner (1989) made abundantly clear, a good deal of the problem stemmed from its refusal to postulate money wage and price stickiness. Its exponents have, therefore, either turned to "real" business cycle theory, which relies on applying the theoretically flawed concept of an aggregate production function to the very problem area, namely the cycle, where its flaws are most likely to prove misleading, and/or have begun to reintroduce the idea of money-wage-price stickiness into their models, sometimes (e.g., King, 1990) trying to find a foundation for the phenomenon in maximising behaviour, and sometimes (e.g., Lucas 1989), taking its existence for granted, but seeking to model the extent to which prices move when they are free to do so. If New-classical and New-Keynesian analysis do indeed merge, as now seems quite likely, the postulate of wage-price stickiness will once again have become uncontroversial, though our understanding of it will also, it is hoped, have been advanced yet further.

\section{VII}

\section{SUMMARY AND CONCLUSION}

What, then, are we to make of this story? Certainly I do not wish to leave my audience with the impression that, in the matter of wage-price stickiness, it was, "all in Marshall" (or "all in Thornton" for that matter). Economics does, on balance, make progress. I have shown that the idea that money wages and prices are sticky has a long history, but I have, I hope, also shown that our understanding of the significance of the phenomenon has systematically 
deepened over time.

In Classical and Neo-classical economics the twin roles of money-wage stickiness is creating real wage stickiness, and in slowing down the real balance effect, were treated as separate and distinct; and as far as the theory of employment was concerned, the former took precedence. Keynes shifted the emphasis of the theory of employment to aggregate demand, and showed how output and employment changes could be viewed as equilibrating movements. He also provided a framework in which the crucial role of wage stickiness in slowing down price level changes and hence the operation the real balance effect, could find its proper place alongside the analysis of real wage changes in that theory. But it was Harberler, Pigou and Patinkin who made us completely aware of this; and it was not until Friedman and Phelps had incorporated expectations about price level behaviour into the Phillips curve that this line of analysis was fully and generally worked out.

A more extreme version of the wage-stickiness doctrine has also had a rather lengthy history. Marshall sometimes argued as if he believed that the secular time path of real wages would be influenced by that of money prices and hence implied that the time path of money wages was, at least within limits, independent of market forces. In the 1930s, the idea that money wages were the prices least susceptible to market forces, so that monetary policy would be wise to accommodate itself to their path became current. British "Keynesians" economics of the post-war period developed this hypothesis, and had it that money wages were institutional or political, rather than economic, variables; while the more moderate American "Keynesianism" postulated the existence of a permanent inflation-unemployment trade off, even after allowing for expectational effects.

The point that I would particularly stress here is that, throughout the history of 
macroeconomics until the early 1970s, debate was always between advocates of greater or lesser stickiness. Until the 1970s, no one used such a phrase as "wage and/or price flexibility" to. characterise continually clearing markets such as are found in so-called, as we can now see, misleadingly, New-classical models, for the simple reason that no school of macroeconomic thought entertained the possibility that markets always cleared. The "new" macroeconomics of the 1970s and 1980s, was, then, new indeed. If however it is nowadays "easy" to turn to wage and price stickiness as an explanation of fluctuations in real income and employment, that is surely, as I have tried to show, because we have 250 years of work on just this question to draw upon, and not because the issues it raises are in any sense intellectually trivial. Hence the revival of interest in wage and price stickiness that is now taking place among "New-classical" macroeconomists, and their apparent willingness to take up what we can now see is an equally misleadingly labelled "New-Keynesian" line of research, is in no sense a symptom of intellectual laziness. It simply represents a return to a line of investigation which began in the mid-18th century and has more than proved its value in the intervening years. 


\section{FOOTNOTES}

1. These authors were aware of Thornton's discussion of the issue, but their own understanding of the significance of the permanent transitory distinction for the matter of price stickiness antedated their discovery that Thornton had anticipated them. I am indebted to Allan Meltzer for discussion of this point.

2. Thomas Humphrey (1990) provides an insightful comparison of the views of Thornton and Ricardo on this matter, arguing correctly that Ricardo's position hinges upon his attaching considerably less weight than Thornton to the possibility of short-term wage stickiness. Nevertheless, Ricardo did not consistently ignore the potentially disruptive effects of falling prices for real variables, as Samuel Hollander (1979) in particular has stressed. See also below pages 6-7 and footnote 4.

3. The fact that Hume is explicit about quantity changes preceding those in prices makes it difficult to interpret his insights as prefiguring those of Lucas (1972). The temporary output and employment effects which occur in New-classical models in response to monetary shocks arise because agents misperceive the price changes which those monetary shocks engender. Nevertheless, Hume's discussion of this matter is more a description of a series of events, than it is an explanation of why those events occur in the order they do, so one should not be dogmatic here.

4. Ricardo, however, did not regard money wage stickiness as being as important a phenomenon as did Malthus, who accorded it a central role in creating the depression which followed the end of the Napoleonic wars. For Ricardo it was sudden deflation, and not deflation in general, which would have adverse consequences. Malthus, of 
course, was far from being an orthodox Classical economist in his treatment of these issues. On all this see Hollander (1979, pp. 523 et. seq.). Note that some commentators, e.g., Humphrey (1990) are unwilling to grant that Ricardo placed as much importance on nominal wage and price stickiness as Hollander finds in his work. This disagreement is probably best resolved by recognising that Ricardo was not always consistent in his treatment of this question. Cf. footnote 2 above.

5. See Fisher $(1911$, p. 70$)$. Note that Wicksell and Fisher offered differing explanations of interest rate stickiness. For Wicksell, banks would have no incentive to raise [lower] rates until they experienced a drain [influx] of reserves. For Fisher, the sluggishness of interest rates stemmed from a slowness on the part of lenders to adjust their expectations of inflation.

6. See, for example, Hawtrey (1913, pp. 41 et. seq.), Robertson (1915, p. 215) Pigou (1913, pp. 75-76), Hayek (1935, p. 106, p. 160) Robbins (1934, pp. 60-61). It is nevertheless worth pointing out that the references to wage stickiness in Hayek's Prices and Production occur only in the second (1935) edition of that book, and that Robbins treats the phenomenon as being of post-war origin, caused, among other things, by overly generous unemployment benefits. The Austrian cycle theory of Hayek and Robbins was old fashioned for its time in treating the boom and crisis phase of the cycle in great detail, and discussing downswing and trough, with their associated unemployment, in a cursory fashion.

7. The emphasis here should be on the adjective theoretical. An extensive, but largely descriptive, literature dealing with unemployment existed even before World War 1 . The very fact that Pigou (1913), already cited, was intended for the general reader attests to 
the social and political importance that attached to unemployment; but in 1913 Pigou, like other writers on the topic (e.g., Beveridge (1909)), wrote as if unemployment was a by-product of various frictions (of which money wage stickiness was but one example) that should be taken account of when standard economic theory was applied to the real world, rather than a fact requiring standard theory itself to be re-examined.

8. On this reading, Keynes' famous 1926 essay "The Economic Consequences of Mr. Churchill", far from prefiguring the General Theory, represents a straightforward combination of orthodox Neo-classical theory and pessimistic judgement about the degree of money wage flexibility to be expected in the British economy.

9. See Keynes (1936) Appendix to Ch. 19.

10. See (1936) pp. 295-298.

11. Indeed, in (1956) Patinkin developed the analysis of a labour market "off" its demand curve, which combined with certain insights of Robert Clower (1965) by Barro and Grossman (1976) and Malinvaud (1977) would eventually establish the complete irrelevance of the level of real wages to "Keynesian" unemployment. The adjective "Keynesian" is here used, in the sense of Malinvaud (1977), to refer to the unemployment which can occur in a simple general equilibrium model if the price level is arbitrarily set at a level that is too high, given the quantity of nominal money, to produce a level of aggregate demand sufficient to absorb the volume of output which firms would be willing and able to supply, were nominal prices free to vary. In such a situation the level of employment is given by the "effective" demand for labour, which is not a function of the real wage, and unemployment can occur if the level of real wages is at, or even below, that which would rule in full employment equilibrium. Barro and 
Grossman (1976) Chs. 1-3 provide the most accessible account of the analysis that produces that conclusion.

12. I have not investigated with any thoroughness the question of whether Myrdal and subsequent contributors to the idea of money wages being largely institutionally determined were explicitly influenced by Marshall's discussion of the matter. Though Monetary Equilibrium does contain references to Marshall, these are invariably general in nature, and none specifically refer to his views on the behavior of wages. That is why I here talk only of the idea of secular money-wage stickiness again becoming current.

13. Though Hicks does not cite Myrdal in (1955), but rather takes as his starting point, some 1929 remarks of Sir Henry Clay on the role of "...ethical standards of 'fair' and 'living' wages [etc.] " in ensuring that "the process of general wage-changes has, we may say, been constitutionalised" he was nevertheless a careful reader of Monetary Equilibrium, having reviewed its German translation for Economica in 1934 (reprinted as ch. 4 of Hicks 1982). In that review, moreover, he drew explicit attention to Myrdal's treatment of wage-price stickiness.

14. As I have argued in Laidler (1990), selective reading of Friedman's presidential address can be used to support either the view that he interpreted the Phillips curve as a disequilibrium wage adjustment relationship, but thought it needed supplementing with an expected inflation variable, or the view that even at this stage he re-interpreted it as an aggregate supply curve. In the Phelps volume too, both interpretations of the Phillips curve are to be found in different essays, without anyone drawing attention to the profound issues which hinge on this matter. The expectations augmented Phillips Curve 
in price inflation $\left(p-p_{. l}\right)$ and output $(y)$ space

$$
\left(p-p_{.1}\right)=f y+\left(p-p_{.1}\right)^{e}
$$

may be derived from the aggregate supply curve

$$
y=1 / f\left(p-p^{e}\right)
$$

by inverting the later, subtracting $p_{.1}$ from each side and noting that

$$
p^{e}-p_{.1} \equiv\left(p-p_{.1}\right)^{e}
$$




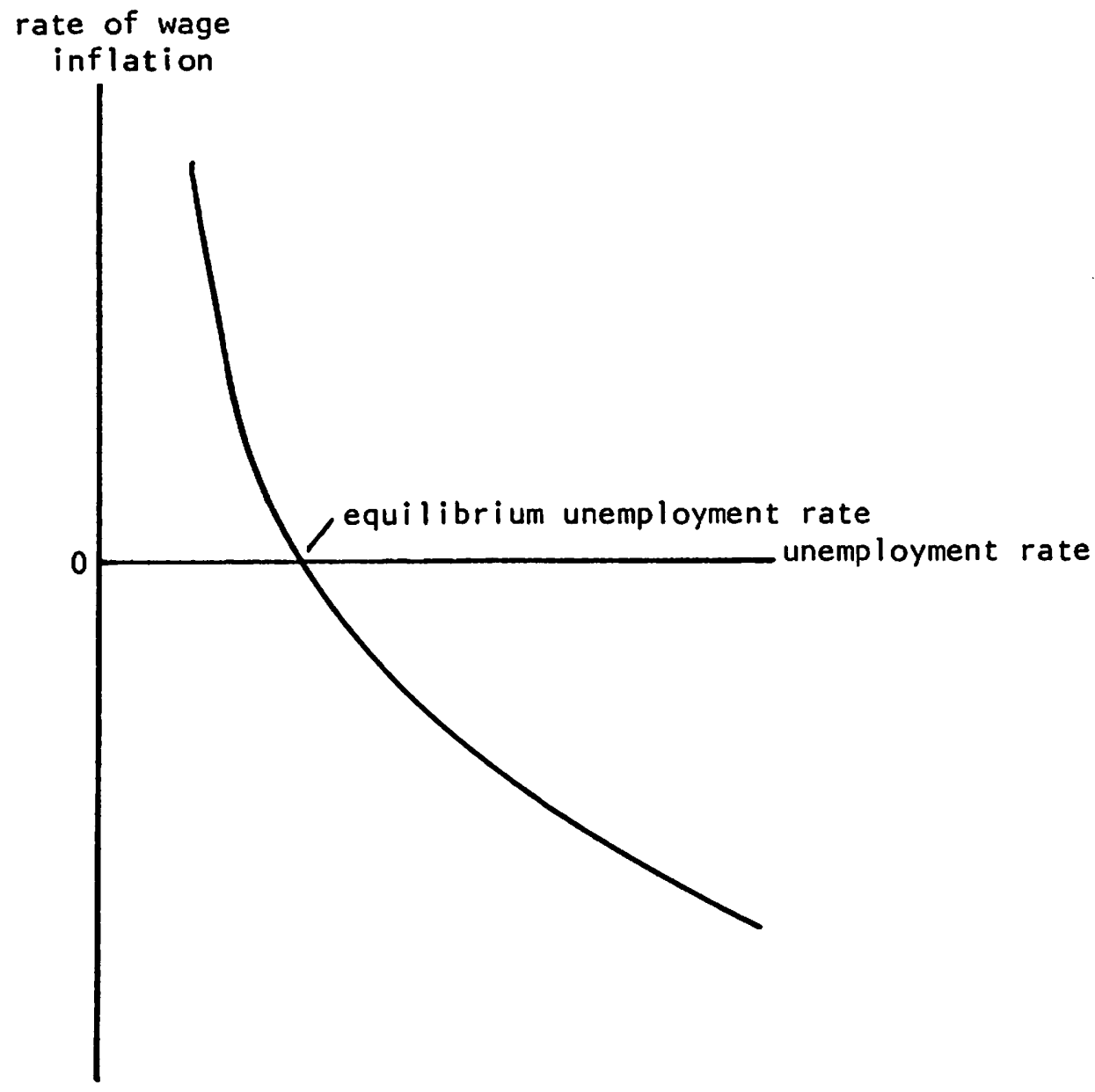

Figure 1: The Phillips Curve

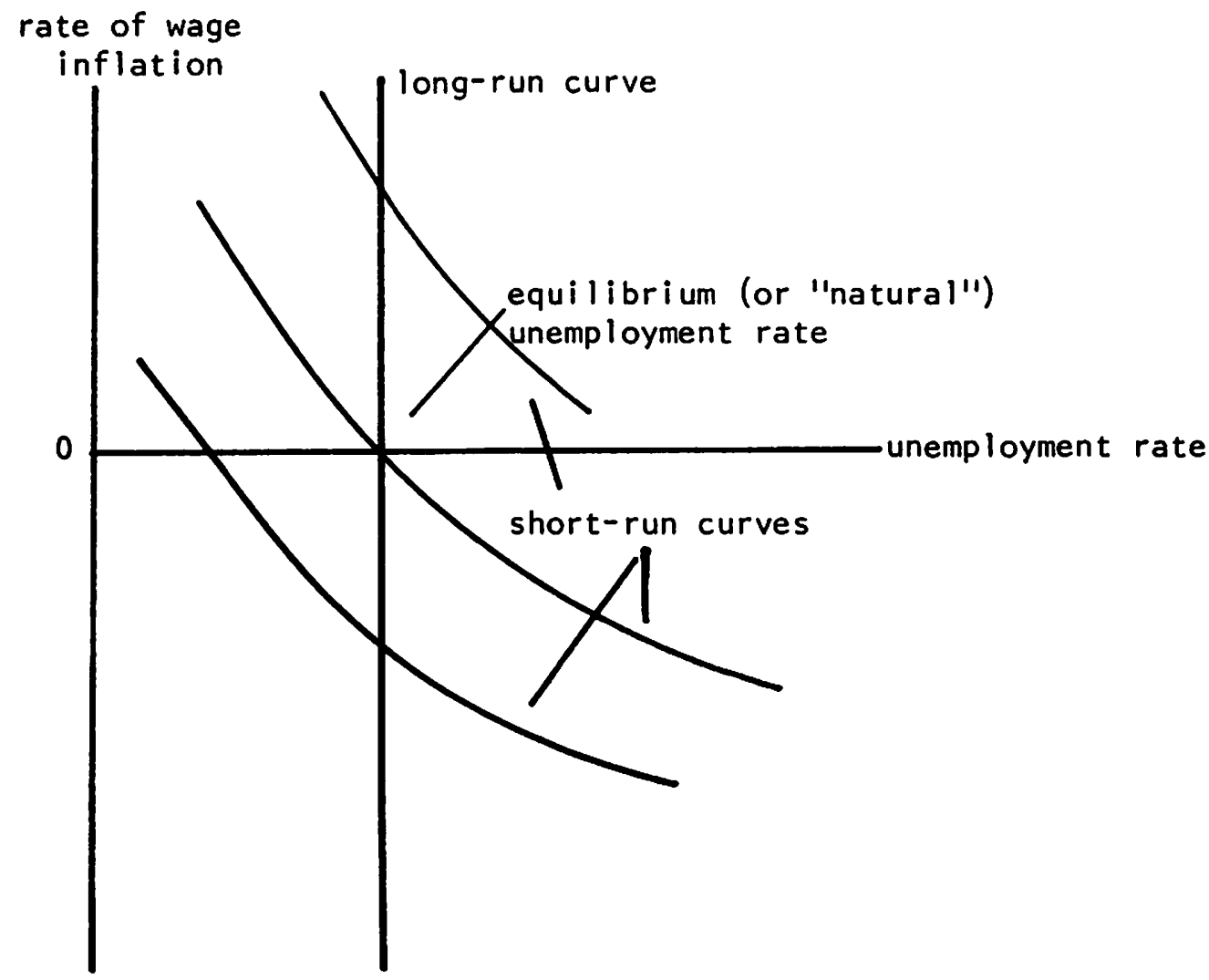

Figure 2: A Vertical Long-Run Phillips Curve and Representative Short-Run Curves 


\section{REFERENCES}

Barro, R.J. and Grossman, H.H. (1976), Money, Employment and Inflation, Cambridge, Cambridge University Press.

Becker, G. and Baumol, W. (1952), "The classical monetary theory: the outcome of the discussion," Economica NS 19 (November), 355-376.

Beveridge, W. (1909), Unemployment, a Problem of Industry, London, Longman and Co.

Brown, A.J. (1955), The Great Inflation, London, Oxford University Press.

Brunner, K. (1989), "The disarray in macroeconomics," in Capie, F. and Wood, G.E. (eds.) Monetary Economics in the 1980s, London, Macmillan.

Cuckierman, A. and Meltzer, A.H. (1983), "Money and economic activity, inventories and business cycles," Journal of Monetary Economics 11, 281-319.

Cannan, E. (1919), The Paper Pound 1797-1821 (The Bullion Report of 1810), London, P.S. King and Son.

Cantillon, R. (1734), Essai sur la nature du commerce en général (Ed. with English tr.), H. Higgs (1931), London, Macmillan.

Clower, R.W. (1965), "The Keynesian counter-revolution -- a reappraisal" in Hahn, F.H. and Brechling, F.R.P. (eds.), The Theory of Interest Rates, London, MacMillan.

Committee on the Working of the Monetary System (1959), Report (The Radcliffe Report) London, HMSO.

Fisher, I. (1911), The Purchasing Power of Money, New York, Macmillan.

Friedman, M. (1968), "The role of monetary policy," American Economic Review, reprinted (1969) in Friedman, M., The Optimum Quantity of Money, London, Macmillan.

Haberler, G. (1939), Prosperity and Depression, 2nd Revised Edition,Geneva, League of Nations, 6th Ed. (1964) New York, Cambridge Mass. Harvard Univ. Press.

Hawtrey, R. (1913), Good and Bad Trade, London, Constable.

Hayek, F.A. von (1935), Prices and Production (2nd. ed), London, Routledge and Kegan Paul.

Hicks, J.R. (1955), "Inflation and the wage-structure," Economic Journal, reprinted as Ch. 16 of Hicks (1982). 
(1982), Money, Interest and Wages: Collected Essays in Economic Theory vol. II Cambridge, Mass., Harvard University Press.

Hollander, S. (1979), The Economics of David Ricardo, Toronto, University of Toronto Press.

Hume, D. (1752), "Of money," in Essays Moral, Political and Literary, reprinted (1963) London, Oxford University Press.

Humphrey, T, (1990), "Ricardo versus Thornton on the Appropriate Monetary Response to Supply Shocks," Federal Reserve Bank of Richmond, Economic Review 76/6 (November/December), pp. 18-24.

Jevons, W.S. (1863), "A serious fall in the value of gold ascertained and its social effects set forth," reprinted (1884) in Investigations in Currency and Finance (ed. H. S. Foxwell), London, Macmillan.

Kaldor, N. (1937), "Prof. Pigou on money wages in relation to unemployment," Economic Journal 47 (December), 745-753.

Keynes, J.M. (1926), "The economic consequences of Mr. Churchill," reprinted in Essays in Persuasion (1931), London, Macmillan.

(1936), The General Theory of Employment Interest and Money, London, Macmillan.

King, R.G. (1990), "Money and business cycles," University of Rochester (mimeo).

Laidler, D. (1971), "The Phillips curve, expectations and incomes policy," in Johnson, H.G. and Nobay, A.R. (eds.), The Current Inflation, London, Macmillan.

(1982), "On Say's law, money and the business cycle," Ch. 3 of Monetarist Perspectives, Deddington, Philip Allan.

(1990), "The legacy of the monetarist controversy," Federal Reserve Bank of St. Louis Quarterly Review.

Lipsey, R.G., "The relationship between unemployment and the rate of change of money wage rates in the United Kingdom 1862-1957," Economica NS 27, 1-37.

Lucas, R.E., Jr. (1972), "Expectations and the neutrality of money," Journal of Economic Theory 4 (2), 103-124.

(1990), "The effects of monetary shocks when prices are set in advance," University of Chicago (mimeo).

Lutz, F. and Mints, L. (eds) (1952), Readings in Monetary Theory, London, Allen and Unwin. 
Malinvaud, E. (1977), The Theory of Unemployment Reconsidered, Oxford, Basil Blackwell. (1890), Principles of Economics, 8th ed. (1920), London, Macmillan. and Marshall, M.P. (1879), Economics of Industry, London, Macmillan.

Marshall, A. (1926), The Official Papers of Alfred Marshall (ed. J. M. Keynes), London, Macmillan.

Mill, J.S. (1844), "On the influence of consumption upon production," in Essays on Some Unsettled Questions in Political Economy, 2nd ed. (1874), London, reprinted (1967), New York, Augustus Kelley.

(1848), Principles of Political Economy, with Some of Their Applications to Social Philosophy 7th ed 1871 reprinted (ed. J. M. Robson) 1965, Toronto, University of Toronto Press.

Muth, J.F. (1961), "Rational expectations and the theory of price movements" Econometrica 29 (May), 315-335.

Myrdal, G. (1931), Monetary Equilibrium, English tr. with minor emendations (1939), London, W. Hodge.

Patinkin, D. (1948), "Price flexibility and full employment," American Economic Review, reprinted with amendments in Lutz and Mints (eds.) (1952).

(1956), Money, Interest and Prices, New York, Harper and Row.

Phelps, E.S. (1967), "Phillips curves, expectations of inflation, and optimal unemployment over time," Economica NS. 34 (August), 254-281.

(et al.) (1970), Microeconomic Foundations of Income and Employment Theory New York, W.W. Norton.

Phillips, A.W. (1958), "The relation between unemployment and the rate of change of money wage rates in the United Kingdom," Economica NS. 25 (November), 283-299.

Pigou, A.C. (1913), Unemployment, London, Williams and Norgate. (1927), Industrial Fluctuations, London, Macmillan. (1933), The Theory of Unemployment, London, Macmillan. 
(1938), "Money wages in relation to unemployment," Economic Journal 48 (March), 134-138.

(1943), "The classical stationary state," Economic Journal 53 (June), 343-351.

(1947), "Economic progress in a stable environment," Economica, reprinted in Lutz and Mints (eds.) (1952).

Ricardo, D. (1810-11), "The high price of gold bullion, a proof of the depreciation of bank notes," reprinted in Vol. III of Works and Correspondence of David Ricardo, ed. P. Sraffa (1951), Cambridge, Cambridge University Press for the Royal Economic Society. (1816), "A proposal for an economical and secure currency," reprinted in Vol. IV of Works....

Robbins, L.C. (1934), The Great Depression, London, Macmillan.

Robertson, D.H. (1915), A Study of Industrial Fluctuations, reprinted 1948, London, LSE.

Smith, A. (1776), An Enquiry into the Nature and Causes of the Wealth of Nations, London reprinted 1976, ed. Campbell, R.H., Skinner, A.S. and Todd, W.B., Oxford, Clarendon Press.

Solow, R.M. (1969), Price Expectations and the Behaviour of the Price Level, Manchester, Manchester University Press.

Thornton, H. (1802), An Enquiry into the Nature and Effects of the Paper Credit of Great Britain, London, reprinted, ed. F.A. von Hayek (1939), London, George Allen and Unwin, reprinted (1962), New York, Augustus Kelley.

Tobin, J. (1972), "Inflation and unemployment," American Economic Review 62 (March), 1-18.

Walras, L. (1874), Élements d'économie politique pure English translation by W. Jaffé from the 1926 definitive edition (1954), Homewood Ill., Richard Irwin.

Wicksell, K. (1915), Lectures in Political Economy Vol. II (2nd Swedish ed.), English translation by E. Claassen (1935), London, Routledge and Kegan Paul. 